\title{
Rainfall Trend Analysis over Bihar: A Parametric Method
}

\author{
Sushanta Sarkar ${ }^{1}$, Birendra Kumar ${ }^{2 *}$ and Sanjay Kumar ${ }^{2}$ \\ ${ }^{1}$ Technical Officer of Agromet (GKMS), Bihar Agricultural College, India \\ ${ }^{2}$ Department of Agronomy, Bihzar Agricultural College, India
}

*Corresponding author

\section{A B S T R A C T}

\section{Keywords \\ Climate change, \\ Linear regression analysis, Monsoon, Seasonal and annual rainfall, Trend analysis}

Article Info

Accepted:

20 January 2021

Available Online:

10 February 2021
This study aims to determine rainfall trend in the Bihar state of India using 70years data recorded between 1950 and 2019. Seasonal (pre-monsoon, monsoon, post-monsoon and winter season) and annual average rainfalls are analyzed to find climate variability and possible trends using parametric method (linear regression analysis). The rainfall trend analysis in Bihar will help the planners to understand the recent scenario of climate change in this state. Existence of trend is being evident from parametric method. Results revealed that except for pre-monsoon season, trends of rainfalls in monsoon, post-monsoon and winter seasons are decreasing including the annual average rainfall during last 70 years.

\section{Introduction}

Variability is the key feature of climate and during the last few decades substantial increase in the temperature and changing rainfall pattern associated with the climate change has drawn a lot of attention, as it affects the food production and available fresh water (Dore, 2005). According to IPCC (2007), the global average surface temperature increased by about $0.74{ }^{\circ} \mathrm{C}$ in the 100 years of 1906-2005 and temperature has risen in the past four decades in the lowest eight kilometres of the atmosphere. The report also states from 1900 to 2005, precipitation has found to either increase or decrease in different parts of the world (IPCC, 2007). An increasing trend of rainfall is found in the north-east Europe, north and South America and central Asia, whereas a decreasing trend is noticed in the Mediterranean and southern Africa and south Asia (IPCC 2007). Australia also shows an increasing trend of rainfall (Suppiah and Hennessy 1998; Nicholls and Lavery 1992). Reduction in the average annual rainfall trend is observed in north and north-east China (Hu et al., 2003; Zhai and Pan 2003), Russia (Savelieva et al., 2000; Peterson et al., 2002), coastal areas of Pakistan (Farooq and Khan 2004), Italy 
(Buffoni et al., 1999), eastern Brazil (Silva 2004) and Kenya (Kipkorir, 2002). The increasing trend of rainfall is observed in west China, while in the Huaihe River basin, Haihe River basin and Yellow River basin a substantial decrease is observed with some moderate variation in the north-east (Zhang et al., 2012). A number ofstudies are available on the rainfall trend and summer monsoon of India (Parthasarathy and Dhar, 1974, 1978; Kothyari and Singh, 1996; Sarkar et al., 2004; Guhathakurta and Rajeevan, 2008) where an increasing trend is observed in Kashmir to the south through the Deccan Plateau (Sen Roy and Balling, 2004). Kumar and Jain (2010) also observed an increasing trend in the seasonal rainfall in Kashmir valley, but monsoon rainfall showed a decreasing trend in Srinagar. A decreasing trend has been observed in north-east India, central northeast India and west-central India by Kumar et al., (2010).

Numerous techniques have been developed for analysis of rainfall trend which involves parametric and nonparametric tests. The nonparametric test includes Mann-Kendal test, Sen's slope estimator, Detrended fluctuation analysis and seasonal Kendall method. Most of the studies have performed non-parametric tests such as Mann- Kendal test, Sens's slope. The parametric linear regression analysis (Nandagiri et al., 1997) can also be used for the analysis of trend. Present study portrays a parametric method of calculating trends for annual average and seasonal average rainfall.

\section{Materials and Methods}

This study work has been done at the department of agronomy, Bihar agricultural college (BAC), Sabour. In this study the rainfall data of 37 districts of Bihar for 70 years, ranging from 1950 to 2019are collected from four meteorological centres viz. Pusa,
Madhepura, Patna and Sabour of Bihar. Here parametric method of identifying the variability is adopted. Rainfall data is analysed by considering seasonal averages viz., Pre-monsoon (March-May), Monsoon (June-September), Post-monsoon (OctoberNovember) and Winter (December-February) and annual average value of rainfall. The methodology adopted to calculate the trend of rainfall involves some steps such as collection of rainfall data, annual averaging of them, data pre-processing to fill missing values or to inspect the anomalies, arrangement of data, calculation of mean values and trend analysis.

\section{Results and Discussion}

The study reflects the present rainfall scenario of Bihar for the last 70 years till 2019, which indicates some notable characteristics. Trend analysis performed over a categorical data shows substantial variations (Fig. 1, 2, 3, 4, 5 and table 1). The annual rainfall graph in the fig. 1 illustrates the prominent decreasing trend of rainfall with $\mathrm{R}^{2}$ value of 0.24.Monsoon and winter periods also show decrease in rainfall, while for post-monsoon period (fig. 4) the decreasing trend is not so prominent. The falling rate is particularly dominant in the monsoon and annual average rainfall graph. It is observed that the frequency of occurrence of pre-monsoon rainfall are less and very uncertain. These less frequent rainfall days have contributed towards positive trend pattern in pre-monsoon season (Fig. 2). Increasing trend may also indicate the increased number of rainy days in pre-monsoon or summer days. The decreasing rainfall trend in monsoon is highly prominent when compared with post monsoon and winter rainfall. Decreasing trend may reflect the decreased intensity of rainfall or number of rainfall days. The factors such as ENSO or ElNino, Southern Oscillation and snow in the Himalaya have an effect on affecting monsoon rainfall. Monsoon is related to the 
active and break phase, and if the break phase continues for a longer period there will be decrease in monsoon rainfall (Ramesh Kumar et al., 2009). In Bihar, the observed decrease in monsoon rainfall and annual average rainfall in the last 70 years may create problems in the agricultural sectors and also in the water supply areas, as the demand is continually increasing with the growing urbanization.

Table.1 Summary table of regression equation with corresponding $\mathrm{R}^{2}$ value during 1950-2019

\begin{tabular}{|l|c|c|}
\hline \multicolumn{1}{|c|}{ Status } & Regression equation & $\mathbf{R}^{\mathbf{2}}$ \\
\hline Annual average & $\mathrm{y}=-4.620 \mathrm{x}+1332$ & 0.240 \\
\hline Pre-monsoon & $\mathrm{y}=0.091 \mathrm{x}+17.95$ & 0.034 \\
\hline Monsoon & $\mathrm{y}=-1.195 \mathrm{x}+288.4$ & 0.318 \\
\hline Post-monsoon & $\mathrm{y}=-0.105 \mathrm{x}+42.38$ & 0.007 \\
\hline Winter & $\mathrm{y}=-0.065 \mathrm{x}+21.54$ & 0.048 \\
\hline
\end{tabular}

Fig.1 Trend of rainfall for annual average during 1950- 2019

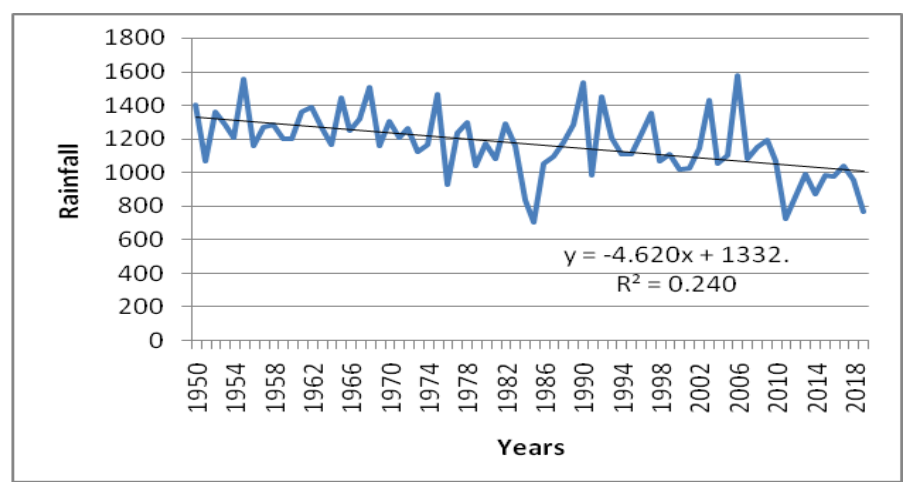

Fig.2 Trend of rainfall in pre-monsoon during 1950- 2019

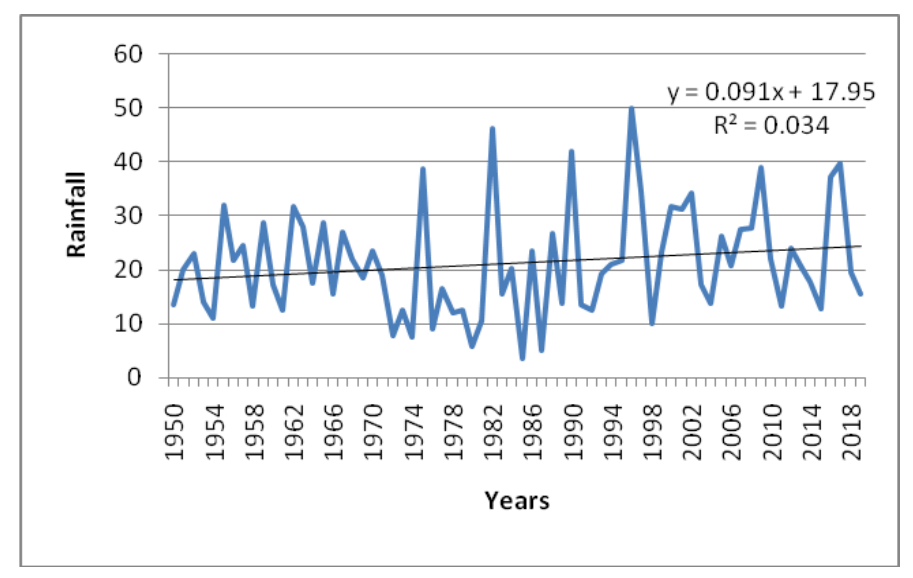


Fig.3 Trend of rainfall in monsoon during 1950- 2019

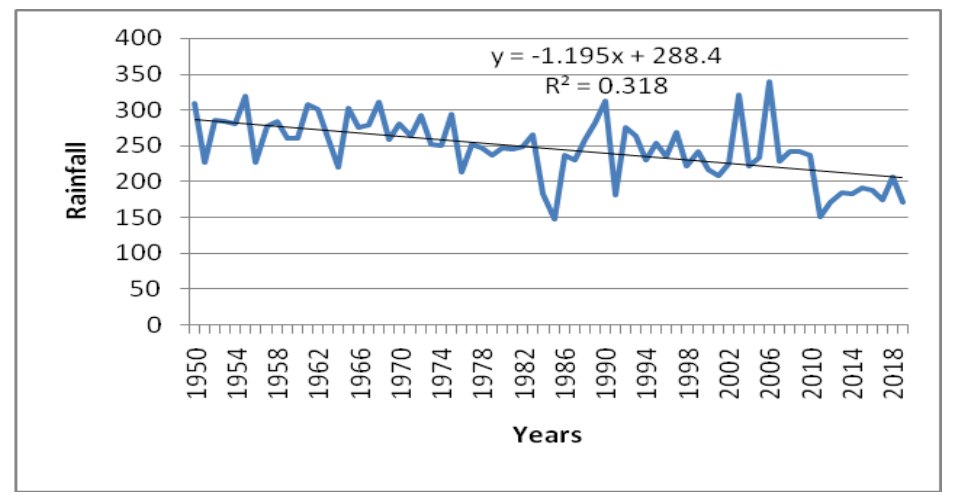

Fig.4 Trend of rainfall in post-monsoon during 1950- 2019

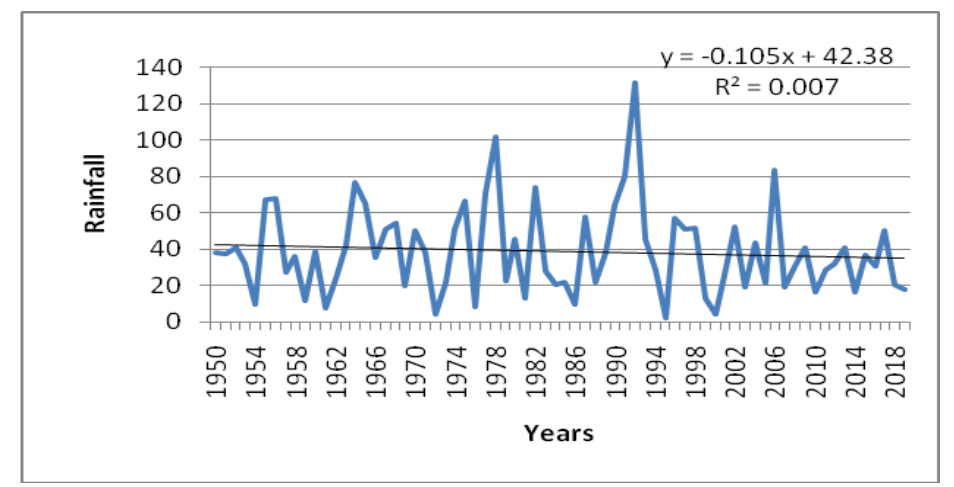

Fig.5 Trend of rainfall in winter during 1950- 2019

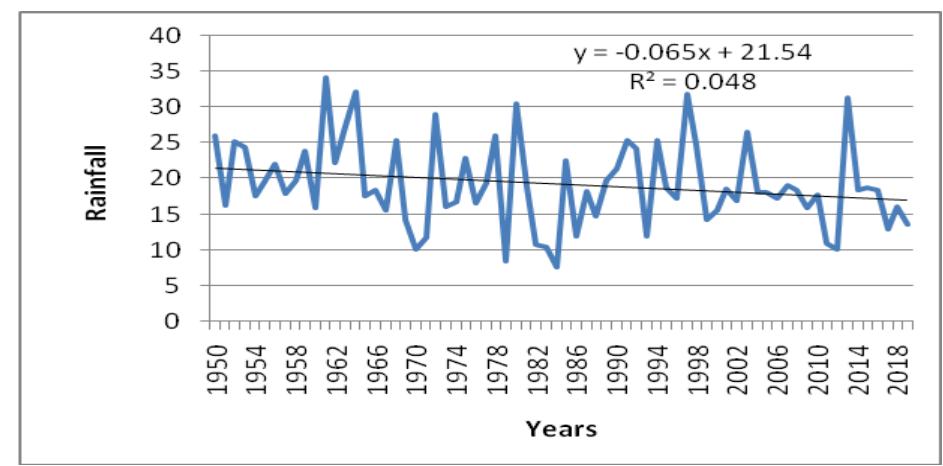

In conclusion this study throws light on the rainfall trends for Bihar district of India. Except for pre-monsoons, the slopes of trend lines are negative and show clearly the decreasing pattern of rainfall in corresponding seasons. Monsoon rainfall as well as annual rainfall is decreasing and is really a call for a tattle.

\section{Acknowledgments}

This study work has been done at the department of agronomy, Bihar agricultural college (BAC), Sabour. We are particularly grateful to the principal, BAC, Sabour, our chairman, colleagues, including staffs of the department of agronomy, Bihar agricultural 
college (BAC), Sabour. This work is funded by the Graminkrishimausamsewa project, Bihar agricultural college (BAC), Sabour. BAU COMMUNICATION NO. 918/210111.

\section{References}

Buffoni, L., Maugeri, M. and Nanni, T. (1999). Precipitation in Italy from 1833 to 1996. TheorApplClimatol, 63:33-40.

Dore, M.H.I. (2005). Climate change and changes in global precipitation patterns: what do we know? Environ Int, 31:1167-1181.

Farooq, A.B. and Khan, A.H. (2004). Climate change perspective in Pakistan. Proc. Capacity Building APN Workshop on Global Change Research, Islamabad, pp 39- 46.

Guhathakurta, P. and Rajeevan, M. (2008). Trends in the rainfall pattern over India. Int J Climatol, 28:1453-1469.

$\mathrm{Hu}, \mathrm{Z} . Z$., Yang, S. and Wu, R. (2003). Longterm climate variations in China and global warming signals. J Geophys Res, 108(D19):4614. doi:10.1029/2003JD003651.

IPCC (Intergovernmental Panel for Climate Change) (2007). Climate Change 2007-the Scientific Basis, Contribution of Working Group I to the Fourth Assessment Report ofthe Intergovernmental Panel for Climate Change.

Kipkorir, E.C. (2002). Analysis of rainfall climate on the Njemps Flats, Baringo District, Kenya. $J$ Arid Environ, 50:445-458.

Kothyari, U.C. and Singh, V.P. (1996). Rainfall and temperature trends in India. Hydrol Process., 10:357-372.

Kumar, V. and Jain, S.K. (2010). Trends in seasonal and annual rainfall and rainy days in Kashmir Valley in the last century. Quatern Int., 212:64-69.

Kumar, V., Jain, S.K. and Singh, Y. (2010).
Analysis of long-term rainfall trends in India. HydrolSci J-Journal des Sciences Hydrologiques, 55(4):484-496.

Nandagiri, L., Thippeswamy, M. and Somanatha, G. S. (1997). Location dependent variability of monsoon rainfall in a tropical region. ISH Journal of Hydraulic Engineering, 3:1, 1-10. DOI:10.1080/09715010.1997.10514598

Nicholls, N. and Lavery, B. (1992). Australian rainfall trends during the twentieth century. Int $J$ Climatol, 12(2):153-163.

Parthasarathy, B. and Dhar, O.N. (1974). Secular variations of regional rainfall over India. Quart $J R$ Met Soc., 100:245-257.

Parthasarathy, B. and Dhar, O.N. (1978). Climate fluctuations over Indian region-Rainfall: a review. Research Report no. RR-025. Indian Institute of Tropical Meteorology, Pune 31.

Peterson, B.J., Holmes, R.M., McClelland, J.W., Vorosmarty, C.J., Lammers, R.B., Shiklomanov, I.A., Shiklomanov, A.I. and Rahmstorf, S. (2002). Increasing river discharge to the Arctic Ocean. Sci., 298:137-143.

Pettitt, A.N. (1979). A non-parametric approach to the change-point detection. Appl. Statist., 28(2):126-135.

Ramesh Kumar, M.R., Krishnan, R., Sankar, S., Unnikrishnan, A.S. and Pai, D.S. (2009). Increasing trend of ' breakmonsoon' conditions over India-role of ocean - atmosphere processes in the Indian Ocean. IEEE Geosci Remote SensLett, 6(2):332-336.

Sarkar, S., Singh, R.P. and Kafatos, M. (2004). Further evidences for the weakening relationship of Indian rainfall and ENSO over India. Geophys Res Lett, 31:L13209. doi:10.1029/2004GL020259.

Savelieva, N.I., Semiletov, I.P., Vasilevskaya, L.N. and Pugach, S.P. (2000). A climate 
shift in seasonal values of meteorological and hydrological parameters for Northeastern Asia. Prog Oceanogr, 47:279-297.

Sen Roy, S. and Balling, R.C. Jr. (2004). Trends in extreme daily precipitation indices in India. Int J Climatol, 24:457466.

Silva, V.P.R. (2004). On climate Variability in northeast of Brazil. J Arid Environ, 58:575-596.

Suppiah. R. and Hennessy K.J. (1998). Trends in total rainfall, heavy rain events and number of dry days in Australia, 19101990. Int J Climatol, 10:1141-1164.

Zhai, P. and Pan, X. (2003). Trends in temperature extremes during 1951-1999 in China. Geophys Res Lett, 30(17):1913. doi:10. 1029/2003GL018004.

Zhang, Q., Li, J., Singh, V.P. and Xu, C. (2012) Copula-based spatio-temporal patterns of precipitation extremes in China. Int J Climatol, 33(5):1140-1152. doi:10.1002/joc.3499.

How to cite this article:

Sushanta Sarkar, Birendra Kumar and Sanjay Kumar. 2021. Rainfall Trend Analysis over Bihar: A Parametric Method. Int.J.Curr.Microbiol.App.Sci. 10(02): 2851-2856.

doi: https://doi.org/10.20546/ijcmas.2021.1002.316 